\title{
Use of ultrasound-guided supraclavicular brachial plexus block as an anesthesia technique in a patient with neurofibromatosis type 1: A case report
}

\author{
Nörofibromatozis tip 1 tanılı hastada anestezi yöntemi olarak ultrason eşliğinde \\ supraklavikuler brakial pleksus blok uygulaması: Olgu sunumu
}

\author{
Emine Aysu ŞALVIZ, ${ }^{1}$ Emre Sertaç BINGGÜL, ${ }^{1}$ Meltem SAVRAN KARADENIZ, ${ }^{1}$ Ömer BERKÖZ, ${ }^{2}$ Erman AK, ${ }^{2}$ \\ Kamil Mehmet TUĞRUL'
}

\begin{abstract}
Summary
Neurofibromatosis type 1 is an autosomal dominant condition characterized by cutaneous and/or plexiform neurofibromas and hyperpigmented café-au-lait spots. It affects multiple endocrine and visceral organs and can be associated with several difficulties such as potential airway (ventilation/intubation) problems, abnormal spinal anatomy, and peripheral neurofibromas. Therefore, anesthesia technique selection becomes more of an issue in terms of avoiding complications and decreasing morbidity and mortality. In the present case, we describe the use of ultrasound and the successful performance of supraclavicular brachial plexus block for surgery on the arm and forearm in a patient with neurofibromatosis type 1.
\end{abstract}

Keywords: Neurofibromatosis type l; supraclavicular brachial plexus block; ultrasound.

\begin{abstract}
Özet
Nörofibromatozis tip 1 kütanöz ve/veya pleksiform nörofibromlarla ve hiperpigmente 'café-au-lait' lekeleriyle karakterize otozomal dominant bir hastalıktır. Endokrin ve visseral organları tutmakta, ve potansiyel havayolu problemleri (ventilasyon/ entübasyon), anormal spinal anatomi ve periferik nörofibromlar gibi çok sayıda zorlukla ilişkili olabilmektedir. Bu sebeplerle komplikasyonlardan kaçınmak, morbidite ve mortaliteyi düşürmek için anestezi yönteminin seçimi daha da önem kazanmaktadır. Biz, bu olgu sunumu ile kol ve önkol cerrahisi geçirecek olan nörofibromatozis tip 1 tanılı hastada ultrason kullanımının ve başarılı supraklavikuler brakial pleksus blok uygulamasının yararııığını ifade etmeye çalıştık.
\end{abstract}

Anahtar sözcükler: Nörofibromatozis tip I; supraklavikuler brakial pleksus blok; ultrason.

\section{Introduction}

Neurofibromatosis type 1 (NF-1) (von Recklinghausen disease) is an autosomal dominant, neuroectodermal disease that affects multiple endocrine and visceral organs by localized neural tissue deposition. ${ }^{[1,2]}$ It is characterized by cutaneous neurofibromas, hyperpigmented café-au-lait spots, and plexiform neurofibromas that tend to infiltrate long peripheral nerves as well as its surrounding tissues. ${ }^{[3]}$

From the view point of anesthetists, several difficulties such as potential airway problems (ventila- tion/intubation), abnormal spinal anatomy, and peripheral neurofibromas make different methods of anesthesia difficult for NF-1 patients. ${ }^{[4]}$ Therefore, pre-operative, detailed physical-especially neurologic-examination, and intracranial, neuroaxial, and airway imaging become more of an issue to decide the anesthesia technique or to decrease morbidity and mortality. Besides the abovementioned reasons, unexpected responses to depolarizing or non-depolarizing drugs during general anesthesia (GA) and availability of ultrasound (US) make regional anesthesia techniques more preferable for patients with NF-1. However, there is still a lack of evidence regarding

\footnotetext{
'Department of Anaesthesiology, İstanbul University Istanbul Faculty of Medicine, İstanbul, Turkey

Submitted: 11.03.2016 Accepted after revision: 16.11.2016 Available online date: 17.04.2018

Correspondence: Dr. Emine Aysu Şalvız. Department of Anaesthesiology, Istanbul University Faculty of Medicine, İstanbul, Turkey.

Phone: +90 - 532 - 5225599 e-mail: aysusalviz@gmail.com

(C) 2018 Turkish Society of Algology
}

${ }^{2}$ Department of Plastic and Reconstructive Surgery, Division of Hand, İstanbul University Istanbul Faculty of Medicine, İstanbul, Turkey 
the success of peripheral nerve blocks (PNBs) and the course of disease after PNBs in these patients.

We describe the utility of US and the successful performance of supraclavicular brachial plexus block (SCB) for surgery on the arm and forearm in a patient with NF-1.

\section{Case Report}

A 20-year-old female $(70 \mathrm{~kg}, 165 \mathrm{~cm})$, an American Society of Anesthesiologists physical status II patient, presented to the Department of Plastic Surgery, Division of Hand Surgery, with a couple of painful neurofibromas, hyperpigmented, diffuse café-au-lait spots, and progressive weakness in her right arm and forearm (Fig. 1). She was scheduled for excision of the neurofibromas and localized skin hyperpigmentation.

Besides NF-1, she also had a past medical history of hypothyroidism and diabetes mellitus type 2 . Her cranial magnetic resonance imaging (MRI) demonstrated demonstrated hamartomatous lesions on the right side of the thalamus and pons. In addition, her right arm MRI showed a neurofibroma-like mass of $5.4 \times 3.4 \mathrm{~cm}$ in size next to the vascular structures at the axillary region and atrophy of the flexor muscles on the arm and forearm. At age 9 years, she had neurofibroma excision from the right axillary region under GA without any complication. Physical examination revealed normal mouth opening, Mallampati Class 2, mild mental retardation, obesity, multiple diffuse, hyperpigmented lesions on the skin, and flexion disability of the right arm and forearm.

The patient was considered to be at high risk with GA due to her pons lesion and mental retardation. In addition, muscle relaxants were preferred not to be used because of their variable responses. After a discussion with the surgical team, SCB was decided to be performed.

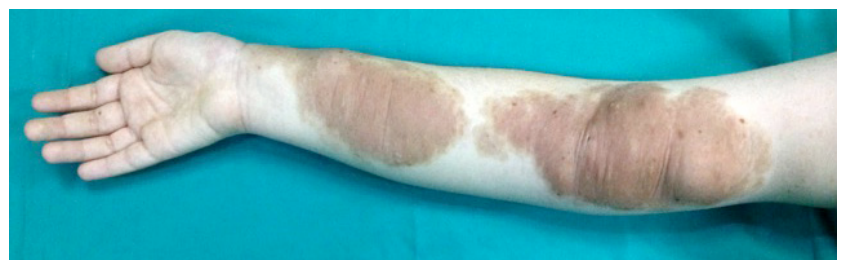

Figure 1. Patient's right arm and forearm with painful neurofibromas, hyperpigmented, diffuse café-au-lait spots, and progressive weakness.
The patient was brought to the operating room and standard monitoring (pulse oximetry, noninvasive blood pressure, and electrocardiography) was carried out. A 20-gauge intravenous (IV) cannula was placed on the left hand of the patient, and a free running infusion of $0.9 \% \mathrm{NaCl}$ was started. Oxygen ( $2 \mathrm{~L} / \mathrm{min}$ ) was provided via a mask. Sedation was achieved with IV midazolam (1 $\mathrm{mg})$ and a loading dose of $1 \mu \mathrm{g} / \mathrm{kg} / \mathrm{h}$ of dexmedetomidine for $10 \mathrm{~min}$, followed by a maintenance infusion dose of $0.5 \mu \mathrm{g} /$ $\mathrm{kg} / \mathrm{h}$.

With the patient in the supine position and head turned away from the side to be blocked, the skin was disinfected. A high-frequency linear ultrasound probe (5-13 MHz, GE Healthcare, Wauwatosa, USA) was placed in the transverse plane immediately superior to the clavicle at approximately its midpoint. The subclavian artery was located with Doppler, and the brachial plexus was visualized anterolaterally as a collection of hypoechoic oval structures (Fig. 2a). No neurofibroma was recognized within the sheath. After $2 \mathrm{~mL}$ of $2 \%$ lidocaine infiltration into the skin, a 22-gauge 50-mm insulated needle (Stimuplex A, B Braun, Melsungen, Germany) was inserted lateral to the probe using an in-plane technique. The correct tip position was confirmed within the brachial plexus sheath by US guidance and a motor response of the forearm and hand by nerve stimulator $(0.5 \mathrm{~mA}$, $0.1 \mathrm{~ms})$. After negative aspiration for blood, the mixture of $10 \mathrm{~mL}$ of $2 \%$ lidocaine and $15 \mathrm{~mL}$ of $0.5 \%$ bupivacaine was incrementally injected in fractionated doses with frequent aspiration. The local anesthetics (LA) spread was observed and SCB was completed (Fig. 2b). The patient did not report any paresthesia or discomfort during the procedure.
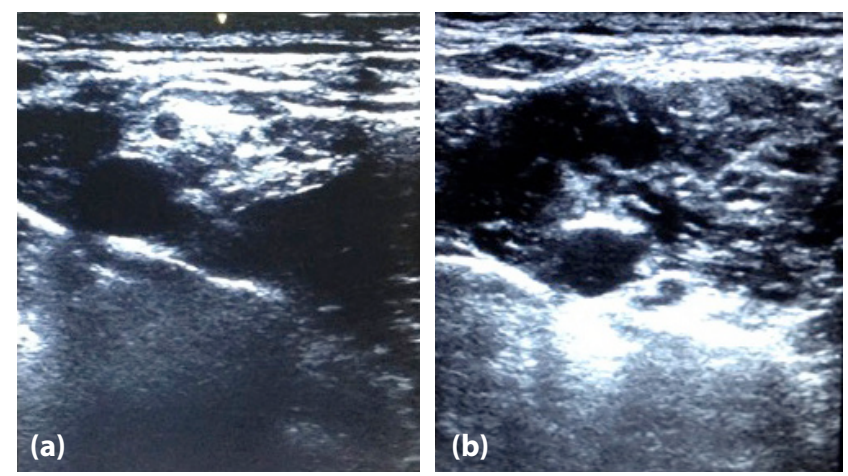

Figure 2. (a) The subclavian artery and anterolaterally identified brachial plexus as a collection of hypoechoic oval structures during the supraclavicular brachial plexus block. (b) Observation of the LA spread within the brachial plexus sheath. 
Block success was assessed as a complete sensory loss to pinprick with a paper clip on the skin over the right arm, forearm, and hand at 30 min and ability to complete surgery with IV sedation using an infusion of $0.5 \mu \mathrm{g} / \mathrm{kg} / \mathrm{h}$ dexmedetomidine while maintaining spontaneous breathing via an oxygen mask. During the surgery, hyperpigmented areas were first excised. Second, two neurofibromas that originated from the lateral cutaneous nerve of the forearm $(11.8 \times 4.3 \mathrm{~cm})$ (branch of the musculocutaneous nerve) and the inferior lateral cutaneous nerve of the arm $(8 \times 3 \mathrm{~cm})$ (branch of the radial nerve) were both excised (Fig. 3). Surgery was completed uneventfully in 60 min with no pain. Motor and sensorial blockage wore off at $12^{\text {th }}$ and $16^{\text {th }} \mathrm{h}$, respectively. Post-operative analgesia consisted of IV paracetamol $2 \times 1 \mathrm{~g}$, which resulted in adequate pain control during the first $48 \mathrm{~h}(\mathrm{NRS} \leq 3)$. The patient did not experience any surgery- or anesthesia-related post-operative complications. After obtaining written informed consent from the patient and her parents for publication of this report, the patient was discharged on post-operative day 2.

\section{Discussion}

NF-1 patients appear with several potential challenges including potential airway difficulty, abnormal spinal anatomy, and peripheral neurofibromas for GA, RA, and PNBs. ${ }^{[4,5]}$ Besides routine physical examinations, neurologic examinations, and radiologic imaging assessments with computed tomography and MRI must be performed in every case. Possible cranial mass and midline shift, increased intracranial pressure, herniation, and spinal neural sheet tumors should be taken into consideration. Then, anesthetists should choose their anesthesia technique balancing the benefits and risks of patient-specific procedures.

In this case, we preferred PNB as SCB to avoid possi-

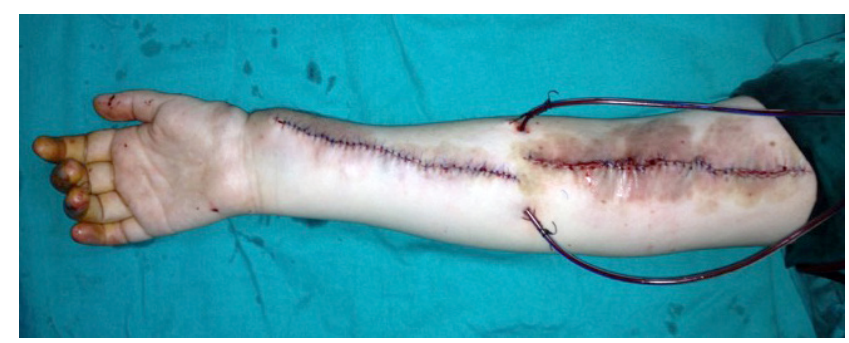

Figure 3. Patient's right arm and forearm after the excision of neurofibromas and localized skin hyperpigmentations. ble post-operative GA-associated problems because of brain stem hamartomas seen on MRI, and we preserved spontaneous ventilation by administering only midazolam and dexmedetomidine for sedation.

The effectiveness of anesthesia and analgesia accomplished with US-guided PNBs are well-described. However, the efficacy and outcomes of PNBs in patients with NF-1 is still limited. ${ }^{[6,7]}$ Ambardekar et al. ${ }^{[8]}$ reported that there is no evidence to show that NF itself is a contraindication to PNB techniques. However, perineural LA injection in the presence of NF may have risks such as ineffective spread, failed block, hemorrhage into the neurofibroma causing nerve compression, or spreading neurofibromatous cells through the needle's track. The use of US becomes more evident as it is a diagnostic tool for neurofibromas and a guide for interventional procedures. Therefore, in our case, we describe the clinical utility of US in the successful performance of SCB for surgery on the arm and forearm in a patient with NF-1.

We decided to block the brachial plexus at the supraclavicular level either to achieve sufficient block for the surgical area or to provide a tumor-free level by walking away from neurofibromas placed at the axillary region and more distally. During the block performance, we performed a US survey to identify possible lesions, to minimize injury to the neurofibromas, and to reduce associated risks. No neurofibroma was identified as there might not have been any within the sheath or it/they might have been unnoticed because of their hypoechoic nodular sonographic appearances, which is exactly as the brachial plexus trunks/divisions at this level. ${ }^{[8-12]}$ Beggs [9] described neurofibromas as well-defined solid hypoechoic masses that have faint distal acoustic enhancement. Reynolds et al. ${ }^{[13]}$ also reported that these tumors are often hypoechoic, with posterior acoustic enhancement. The Doppler function was used to highlight vasculature structures and US allowed us to insert the needle through the sheath without injuring the hypoechoic structures and see the LA spread. Blockade onset time and duration were definitely normal, and it was successful both for anesthesia and post-operative analgesia, with no complication.

Nerve stimulator-guided axillary brachial plexus 
block $^{[1]}$ and US-guided sciatic nerve/popliteal block performances have previously been reported in NFdiagnosed patients, ${ }^{[6-8]}$ however, to our knowledge, there have been no data on SCB.

In conclusion, US-guided SCB can be used as an alternative anesthesia and post-operative analgesia technique in patients with NF-1. At this point, US guidance helped us succeed and avoid neurofibroma puncture. Nevertheless, it is hard to prove the safety and efficacy of regional anesthesia in all NF cases; therefore, we recommend that anesthesia technique preferences to be individualized.

\section{Conflict-of-interest issues regarding the author- ship or article: None declared.}

\section{Peer-rewiew: Externally peer-reviewed.}

\section{References}

1. Inan N, Basar H, Turkoglu M, Gulec H, Tezer E, Baltaci B. The anesthetic approach in a patient with type 1 neurofibromatosis with multiple deformities. Turk J Med Sci 2008;38:477-80.

2. McSwain JR, Doty JW, Wilson SH. Regional anesthesia in patients with pre-existing neurologic disease. Curr Opin Anaesthesiol 2014;27(5):538-43. [CrossRef]

3. Morse RP. Neurofibromatosis type 1. Arch Neurol 1999;56(3):364-5. [CrossRef]
4. Hirsch NP, Murphy A, Radcliffe JJ. Neurofibromatosis: clinical presentations and anaesthetic implications. $\mathrm{Br} \mathrm{J}$ Anaesth 2001;86(4):555-64. [CrossRef]

5. Mercier FJ, Dounas M, Bouaziz H, Lhuissier C, Benhamou D. Intravenous nitroglycerin to relieve intrapartum fetal distress related to uterine hyperactivity: a prospective observational study. Anesth Analg 1997;84(5):1117-20. [CrossRef]

6. Desai A, Carvalho B, Hansen J, Hill J. Ultrasound-guided popliteal nerve block in a patient with malignantdegeneration of neurofibromatosis 1. Case Rep Anesthesiol 2012;2012:753769.

7. Rocco ML, Rosenblatt MA. Ultrasound-guided peripheral nerve block in a patient with neurofibromatosis. Reg Anesth Pain Med 2011;36(1):88-9. [CrossRef]

8. Ambardekar AP, Ganesh A, Schwartz AJ. The value of ultrasound in the safe care of a patient with neurofibromatosis. Anesthesiology 2013;118(5):1206. [CrossRef]

9. Beggs I. Sonographic appearances of nerve tumors. J Clin Ultrasound 1999;27(7):363-8. [CrossRef]

10. Beggs I. Pictorial review: imaging of peripheral nerve tumours. Clin Radiol 1997;52(1):8-17. [CrossRef]

11. Höglund M, Muren C, Engkvist O. Ultrasound characteristics of five common soft-tissue tumours in the hand and forearm. Acta Radiol 1997;38(3):348-54. [CrossRef]

12. Manickam BP, Perlas A, Chan VW, Brull R. The role of a preprocedure systematic sonographic survey in ultrasound-guided regional anesthesia. Reg Anesth Pain Med 2008;33(6):566-70. [CrossRef]

13. Reynolds DL Jr, Jacobson JA, Inampudi $P$, Jamadar DA, Ebrahim FS, Hayes CW. Sonographic characteristics of peripheral nerve sheath tumors. AJR Am J Roentgenol 2004;182(3):741-4. [CrossRef] 